\title{
PENGARUH BODY IMAGE DAN KECERDASAN EMOSI TERHADAP DEPRESI PADA REMAJA
}

\author{
Aniq Ayu Bestari \\ UIN Syarif Hidayatullah \\ Jakarta \\ aniqayubest@gmail.com
}

\author{
Zulfa Indira Wahyuni \\ Himpunan Psikologi \\ Indonesia \\ zulfara@yahoo.com
}

\begin{abstract}
This study was conducted to discover factors which affect teenage depression. Previous studies indicate that there are gender effect, age of puberty, and psychological variables, body image and emotion intelligence on teenage depression. Quantitative approach used in this study using multiple regression analysis. Sample of this study were 200 junior high school students who were chosen using nonprobability sampling technique. In this study, researchers modified data collecting instruments, Multidimensional Body-Self Relation Questionnaire-Appearance Scale, BarOn Emotional Quotient Inventory, and Beck Depression Inventory. Result of this study indicates that there are significant effects of body image, emotional intelligence, gender, and age of puberty on teenage depression. Significant variables are appearance orientation, body size categorization, body image anxiety, and interpersonal ability of emotional intelligence.
\end{abstract}

Keywords: Body Image, Appearance Orientation, Body Size Categorization And Body Image Anxiety, Emotional Intelligence, Interpersonal Ability, Depression, Teenage

\section{Abstrak}

Penelitian ini dilakukan untuk mengetahui faktor-faktor yang mempengaruhi depresi remaja. Penelitian terdahulu menunjukkan adanya pengaruh jenis kelamin, usia pubertas dan variabel psikologis body image dan kecerdasan emosi terhadap depresi remaja. Penelitian ini menggunakan pendekatan kuantitatif dengan analisis regresi berganda. Sampel berjumlah 200 siswa sekolah SMPN yang diambil dengan teknik non-probability sampling. Dalam penelitian ini, penulis memodifikasi instrumen pengumpulan data, yaitu MBSRQ-AS (Multidimensional Body-Self Relation Questionnaire-Appearance Scales), BarOn EQ-i (BarOn Emotional Quotient Inventory), dan BDI (Beck Depression Inventory). Hasil penelitian menunjukkan adanya pengaruh signifikan dari body image, kecerdasan emosi, jenis kelamin dan usia pubertas terhadap depresi remaja. Variabel signifikan adalah orientasi penampilan, kategorisasi ukuran tubuh dan kecemasan menjadi gemuk dari variabel body image dan kemampuan intrapersonal dari variabel kecerdasan emosi.

Kata Kunci: Body Image, Orientasi Penampilan, Kategorisasi Ukuran Tubuh Dan Kecemasan Menjadi Gemuk, Kecerdasan Emosi, Kemampuan Intrapersonal, Depresi, Remaja 
Diterima: 15 Oktober 2014 2014
Direvisi: 8 November

Disetujui: 17 November 2014 


\section{PENDAHULUAN}

Masa remaja dikenal dengan masa penuh perubahan. Perubahan yang menjadikan remaja tidak lagi dimanja, mulai belajar mandiri, berhubungan dengan orang dan lingkungan yang lebih luas, membentuk pribadi yang dicintai teman sebaya, dan belajar untuk mengambil keputusan sendiri.

Perubahan-perubahan yang dialami remaja sudah sesuai dengan tahap perkembangan. Berjalan baik atau tidak, akan mempengaruhi sikap dan perilaku di tahap perkembangan selanjutnya. Mengetahui kondisi remaja dan masalahmasalahnya diperlukan agar mampu melewati tugas perkembagan dengan baik dan mampu mencegah permasalah yang mungkin terjadi.

Penelitian ini fokus pada remaja awal karena pada masa ini banyak perubahan dalam berbagai aspek kehidupan. Periode ini memiliki resiko, sebagian remaja mengalami masalah dalam menghadapi berbagai perubahan yang terjadi secara bersamaan dan membutuhkan bantuan dalam mengatasi bahaya saat menjalani masa ini (Papalia, Old \& Feldman, 2009). Perubahan yang secara bersamaan terjadi dapat dilihat dari aspek sosial dan fisik. Dewasa ini, remaja usia 12 tahun sudah mengalami pubertas dan bersamaan dengan itu remaja harus pindah sekolah dari Sekolah Dasar menuju Sekolah Menengah Pertama.

Pada saat perpindahan sekolah, remaja berusaha membangun interaksi dengan orang-orang baru dan dalam lingkungan yang baru, sekaligus menyesuaikan diri dengan perubahan fisik yang terjadi saat pubertas. Pada masa ini remaja membutuhkan mental yang kuat dan dukungan yang besar untuk mampu melewati tugas perkembangan yang secara bersamaan dialami.

Pubertas ditandai dengan menstruasi bagi remaja perempuan dan mimpi basah bagi remaja laki-laki. Menstruasi yang dialami perempuan mengikutsertakan masalah-masalah fisik lainnya, seperti sakit kepala, sakit punggung, pembengkakan lutut, bertambah gemuk dan mengalami perubahan emosi seperti perubahan suasana hati, sedih, gelisah, dan kecenderungan menangis tanpa sebab yang jelas.

Pubertas pada masa remaja melibatkan adanya body image. Remaja mulai menyibukkan diri dengan penampilan dan membentuk konsep tubuh yang ideal (Santrock, 2002). Sedikit 
remaja yang mengalami kepuasan tubuh sebagai akibat dari adanya pubertas. Ketidakpuasan lebih banyak dialami di beberapa bagian tubuh tertentu. Kegagalan mengalami kepuasan

134 
tubuh menjadi salah satu penyebab timbulnya konsep diri yang kurang baik dan kurangnya harga diri selama masa remaja (Mahoney \& Finch dalam Hurlock, 1980).

Jerawat dan gangguan kulit lainnya juga menjadi sumber kegelisahan bagi remaja laki-laki maupun perempuan. Suburnya jerawat membuat remaja laki-laki semakin prihatin. Keprihatinan lebih besar pada remaja laki-laki karena remaja laki-laki sadar bahwa jerawat mengurangi daya tarik fisik dan karena remaja laki-laki tidak dapat menggunakan kosmetik untuk menutupinya seperti remaja perempuan (Roberts \& Ludford dalam Hurlock, 1980). Keprihatian pada remaja timbul karena adanya kesadaran bahwa daya tarik fisik berperan penting dalam hubungan sosial.

Dampak pubertas menyebabkan kekhawatiran pada remaja. Jika remaja tidak siap mental, tidak memiliki kemampuan untuk mengatur stres ditambah lagi dengan pesimis dalam menghadapi berbagai macam perubahan yang sudah saatnya untuk dijalani, maka lagi-lagi tidak sedikit remaja yang mengalami depresi. Pikiran negatif pada remaja, tentang kekhawatiran akan adanya penolakan, kehilangan, atau adanya rasa ketergantungan yang tinggi, akan meningkatkan gangguan mood (DSM-IV-TR, 2000).

Depresi dalam hal ini adalah proses kognitif yang keliru atau cara pandang yang negatif tentang diri sendiri, lingkungan dan masa depan, khususnya yang dialami oleh remaja dengan beberapa perubahan yang terjadi didalamnya. Perubahan bentuk tubuh yang terlihat dan ekspektasi-ekspektasi mempunyai bentuk tubuh yang ideal, menjadikan body image salah satu faktor penyebab depresi. Proses body image dapat disesuaikan atau tidak akan berdampak pada fungsi psikososial dan kualitas hidup.

Selain faktor body image, faktor lain dalam hal emosi juga mempengaruhi depresi pada remaja. Remaja dikenal sebagai seseorang yang moody, yaitu kondisi emosi yang tidak stabil. Ini mungkin berpengaruh pada perubahan hormonal yang dialami remaja. Ketika remaja mengalami pubertas, hormon menyebabkan perubahan seksual dan menimbulkan perasaanperasaan baru dan belum pernah dirasakan sebelumnya. Keterbatasan secara kognitif untuk mengolah perubahan tersebut dapat membawa perubahan besar dalam fluktuasi emosi. 
Mencapai kematangan emosi merupakan tugas perkembangan yang sangat sulit bagi remaja (Santrock, 2007). Proses pencapaiannya sangat dipengaruhi oleh kondisi sosioemosional lingkungannya, terutama lingkungan keluarga dan kelompok teman sebaya. Apabila lingkungan 
tersebut kondusif, dalam arti penuh dengan keharmonisan, saling percaya, saling menghargai, dan penuh tanggung jawab, maka remaja cenderung dapat mencapai kematangan emosi. Remaja dengan ciri moody, yang secara kognitif terbatas dalam menghadapi perubahan, perlu memiliki kecerdasan emosi dalam mengatasi stres selama masa transisi yang signifikan ini. Selain faktor body image dan kecerdasan emosi, ada faktor demografi yang mempengaruhi depresi, yaitu jenis kelamin dan usia pubertas. Remaja perempuan dua kali lebih banyak dari pada remaja laki-laki yang mengalami depresi. Pada usia antara 11 hingga 13 tahun ada peningkatan kecenderungan depresi pada perempuan. Pada usia 15 tahun perempuan memiliki kecenderungan dua kali lebih besar dari pada laki-laki terkena depresi. Pada umumnya remaja mengalami menstruasi atau mimpi basah pada usia12 tahun. Perbedaan usia pubertas pada remaja dibagi menjadi dua kategori yaitu cepat dan lambat. Remaja yang pubertas lebih cepat sekitar usia 10 atau 11 tahun cenderung mengalami depresi (Kaltiala et al., 2003).

\section{METODE}

Dalam penelitian ini sampel berjumlah 200 orang remaja yang tinggal di daerah Cipayung Jakarta Timur. 100 remaja perempuan dan 100 remaja laki-laki.

Teknik yang digunakan dalam pengambilan sampel adalah teknik non-probability sampling yang berarti tidak semua anggota populasi memiliki kesempatan yang sama untuk menjadi subjek penelitian.

\section{Pengukuran}

BDI (Beck Depression Inventory)

BDI digunakan untuk mengukur gejala depresi pada sampel usia 13 tahun keatas yang sesuai dengan variabel penelitian. Alat ukur ini menggunakan Bahasa Inggris lalu diadaptasi ke dalam Bahasa Indonesia. BDI (Beck Depression Inventory) terdiri dari 21 item dan menggunakan skala Likert dalam pengisiannya dengan rentang 0 sampai 3 . Pada penelitian ini satu item dieliminasi (ketertarikan seksual) karena hasil try out pada 10 remaja, enggan mengisi item mengenai hubungan seksual tersebut. 
136 
MBSRQ-AS (The Multidimensional Body Self Relations Questionnaire-Appearance Scale)

Skala ini dibuat secara individu dengan berpedoman pada skala MBSRQ (The Multidimensional Body Self Relations Questionnaire). Skala ini terdiri dari 32 item, evaluasi penampilan (6 item), orientasi penampilan (11 item), kepuasan terhadap bagian tubuh ( 9 item), kecemasan menjadi gemuk ( 4 item), dan pengkategorisasian ukuran tubuh ( 2 item). Pengisian skala ini menggunakan skala Likert dari rentang 1 sampai 5.

The BarOn Emotional Quotient Inventory

Alat ukur ini mengukur kecerdasan emosi pada usia tujuh sampai 18 tahun. Skala ini juga dibuat secara individu yang berpedoman pada indikator-indikator di setiap aspek. Dalam skala ini terdiri dari 39 item dan menggunakan skala Likert untuk pengisiannya dengan rentang 1 sampai 5, yaitu dari sangat tidak setuju (skala 1 ) sampai sangat setuju (skala 5).

\section{Prosedur}

Remaja awal adalah usia pertama kali pubertas yang terdapat banyak perubahan dalam berbagai aspek. Pemilihan sekolah di tingkat menengah pertama kelas VII dan VIII dikarenakan target sampel termasuk dalam usia remaja awal. Penelitian ini bertujuan untuk melihat tingkat depresi remaja di Jakarta Timur. Pemilihan sekolah dipilih secara acak. Sampel diberikan kuesioner dan mengisinya tanpa diberikan batas waktu.

\section{HASIL}

Tabel

Model Summary

\begin{tabular}{|c|c|c|c|c|}
\hline Model & $\mathbf{R}$ & R Square & $\begin{array}{c}\text { Adjusted R } \\
\text { Square }\end{array}$ & $\begin{array}{c}\text { Std. Error of } \\
\text { the } \\
\text { Estimate }\end{array}$ \\
\hline 1 & $.527^{a}$ & .278 & .236 & 8.274 \\
\hline
\end{tabular}

Dari tabel diatas dapat dilihat bahwa perolehan $R$-square sebesar 0.278 atau $27.8 \%$. Artinya proporsi varians dari depresi 
yang dapat dijelaskan oleh semua independent variable adalah sebesar $27.8 \%$, sedangkan $72.2 \%$ sisanya

13

7 
dipengaruhi oleh variabel lain diluar penelitian ini. Selanjutnya, diperoleh empat koefisien regresi yang signifikan yaitu kemampuan intrapersonal, kategori ukuran tubuh, kecemasan menjadi gemuk dan orientasi penampilan.

Sumbangan yang diberikan oleh variabel kemampuan intrapersonal terhadap depresi adalah sebesar $11.1 \%$. Sumbangan yang diberikan oleh variabel kategori ukuran tubuh terhadap depresi adalah sebesar $8.1 \%$. Sumbangan yang diberikan oleh variabel kecemasan menjadi gemuk terhadap depresi adalah sebesar $3.2 \%$, dan sumbangan terakhir yang signifikan dari variabel orientasi penampilan terhadap depresi adalah sebesar $3.1 \%$.

\section{DISKUSI}

Secara umum, body image dan kecerdasan emosi berpengaruh terhadap depresi remaja. Hal ini sejalan dengan penelitian yang dilakukan oleh Adel Tannous dan Jehan Matar (2010) yang menemukan bahwa terdapat pengaruh kecerdasan emosi terhadap depresi remaja Jordania. Hasil penelitian Brausch dan Gutierrez (2009) juga menunjukkan bahwa body image memiliki pengaruh terhadap depresi remaja Amerika.

Berdasarkan dari hasil penelitian dan uji hipotesis yang telah dilakukan menunjukkan adanya pengaruh yang signifikan dari variabel kecerdasan emosi yaitu kemampuan intrapersonal, dan body image yaitu kategori ukuran tubuh, kecemasan menjadi gemuk, dan orientasi penampilan.

Remaja dengan tugas-tugas perkembangan yang begitu banyak dari berbagai aspek kehidupan, memerlukan kecerdasan emosi yang positif untuk dapat melalui tugas tersebut dengan baik. Apabila tugas-tugas tersebut berhasil diselesaikan dengan baik, maka akan tercapai kepuasan, kebahagian dan penerimaan dari lingkungan. Keberhasilan individu memenuhi tugas-tugas itu juga akan menentukan keberhasilan individu memenuhi tugas-tugas perkembangan pada fase berikutnya (Retnowati, 2009).

Variabel yang memiliki pengaruh signifikan terhadap depresi selanjutnya adalah kategori ukuran tubuh. Kategori ukuran tubuh adalah persepsi dan penilaian individu terhadap berat badan yang dimiliki, seperti kekurangan berat badan atau kelebihan berat badan. Remaja dengan kategori kegemukan dan obesitas menderita diskriminasi sosial, terutama 
138 
dari teman sebaya, yang dapat menambah rasa depresi atau membuat self esteem remaja tersebut rendah (Ross dalam APA, 2010).

Variabel berikutnya adalah kecemasan menjadi gemuk signifikan mempengaruhi depresi. Dapat diartikan bahwa, semakin tinggi remaja cemas menjadi gemuk, maka semakin tinggi pula depresi remaja.

Dengan tugas perkembangan sosial remaja yaitu mencapai hubungan yang baru dengan teman sebaya baik sesama jenis maupun lawan jenis dan mencapai peran sosial, kecemasan dengan bentuk tubuh wajar terjadi di kalangan remaja. Remaja ingin tampil proporsional agar menarik dan tercapai tugas perkembangan tersebut. Remaja yang berusaha konsisten untuk mengontrol berat badan, mungkin akan gagal sewaktu-waktu. Kegagalan tersebut kemudian mengarah pada perasaan tidak menyenangkan, perasaan bersalah, tidak ada harapan, dan jika perasaan-perasaan tersebut terjadi lebih lama, dapat menyebabkan depresi.

Variabel terakhir yang menyebabkan depresi remaja dalam penelitian ini adalah orientasi penampilan. Orientasi penampilan adalah perhatian individu terhadap penampilan diri dan usaha yang dilakukan untuk memperbaiki dan meningkatkan penampilan diri. Dapat diartikan bahwa, semakin tinggi keinginan remaja untuk tampil sempurna, maka semakin tinggi pula depresi.

Waktu yang lama dan upaya yang besar untuk mencapai kesempurnaan sudah mulai dilakukan dalam aspek penampilan, contohnya seperti perhatian terhadap jerawat, kacamata, berat badan, atau raut wajah. Remaja yang hanya fokus pada orientasi penampilan tanpa fokus pada orientasi kematangan emosi, dapat mempengaruhi kondisi psikologis. Ketika upaya yang sudah dilakukan tidak menghasilkan efek yang signifikan, remaja cenderung merasa depresi.

\section{DAFTAR PUSTAKA}

Papalia, Diane E., Olds, Sally Wendkos., \& Feldman, Ruth Duskin.

Human development, Perkembangan manusia.Brian Marwensdy (terj).

(2009). Jakarta: Salemba Humanika.

Hurlock, Elizabeth B. (1980). Development psychology: A life span approach. 
New York: McGraw Hill.

Santrock, John W. Child development, Perkembangan anak. Mila Rachmawati

\& Anna Kuswanti (terj). (2007). Jakarta: Erlangga.

Kaltiala, Riittakerttu \& Heino., Marrttunen, Mauri., Rantanen,

Paivi., Rimpela, Matti. (2003). Early puberty is associated

with mental

13

9 
Pengaruh Body Image dan Kecerdasan Emosi terhadap Depresi pada Remaja

health problems in middle adolescence. Social Science \& Medicine, 57,1055-1064.

Developing adolescents. (2002). American Psychological Association. 


\title{
PENGARUH KECERDASAN EMOSIONAL DAN GAYA KELEKATAN TERHADAP PENGAMBILAN KEPUTUSAN KARIR PADA SISWA DAN SISWI SMA NEGERI 36 JAKARTA
}

\author{
Denny Sekar Taji \\ Solicha \\ UIN Syarif Hidayatullah Jakarta \\ dennysekartaji@gmail.com
}

\begin{abstract}
This study aimed to examine the effect of emotional intelligence and attachment styles to the career decision making on SMAN 36 Jakarta. This study used a quantitative approach with multiple regression analysis. The sample totaled 237 high school students were taken using a non probability sampling technique. In this study, researcher modified the instrumental data, namely Assessment of Career Decision Making (ACDM), Wong And Law Intelligence Scale (WLEIS) and Adult Attachment Scale (AAS). Research data analysis using SPSS software, while for the construct validity testing using CFA. Based on the analysis of data, there is three research conclusions. The first conclusion is that there is a significant relationship between emotional intelligence and attachment styles to rational career decision making on students. It was found that the variable that have a significant effect is the use of emotions. The second conclusion is there is no significant relationship between emotional intelligence and attachment styles to the intuitive career decision making on students. It was found that the variable that have a significant effect is the avoidance attachment style. The final conclusion there is a significant relationship between emotional intelligence and attachment styles to dependent career decision making on students. It was found that the variable that have a significant effect is self emotions appraisal and regulation of emotions. For further study, the researcher suggested using other variables such as personality, social support, self efficacy and demographic variables.
\end{abstract}

Keywords: Career decision making; emotional intelligence; attachment style

Abstrak
Penelitian ini bertujuan untuk menguji pengaruh dari kecerdasan
emosional dan pola kelekatan pada pengambilan keputusan untuk
memilih karir di SMAN 36 Jakarta. Penelitian ini menggunakan
pendekatan kuantitatif dengan analisis regresi berganda. Penelitian ini
mengambil 237 murid sebagai responden dengan menggunakan
teknik non-probability sampling. Dalam penelitian ini, peneliti
menggunakan instrumen yang telah dimodifikasi, yaitu Assessment of
Carrer Decision Making, skala kecerdasan Wong dan Law (WLEIS), dan
skala kelekatan orang dewasa (AAS). Data dianalisis dengan
menggunakan SPSS dan konstruk validitas menggunakan CFA.


Terdapat 3 kesimpulan berdasarkan hasil analisis. Pertama, ada pengaruh signifikan kecerdasan emosional dan pola kelekatan pada pengambilan keputusan rasional. Kedua, tidak ada pengaruh signifikan kecerdasan emosional dan pola kelekatan pada pengambilan keputusan intuitif. Terakhir, ada 
pengaruh signifikan kecerdasan emosional dan pola kelekatan pada pengambilan keputusan dependen. Pengaruh signifikan ada pada penilaian emosi diri dan regulasi emosi. Penelitian selanjutnya disarankan untuk menggunakan variabel seperti kepribadian, dukungan sosial, kepercayaan diri, dan demografi.

Kata Kunci: Pengambilan Keputusan Karir, Kecerdasan Emosional, Pola Kelekatan

Diterima: 4 November 2014

2014

Direvisi: 29 November

Disetujui: 10 Desember 2014

\section{PENDAHULUAN}

Sukardi (1993) menyatakan bahwa pengambilan keputusan karir merupakan suatu proses dimana seseorang mengadakan suatu seleksi terhadap beberapa pilihan dalam rencana masa depan. Penjelasan lebih lanjut dikemukakan oleh Munandir (1996), yang menyatakan bahwa keputusan karir yang dimaksud adalah keputusan yang diambil secara arif dan teliti serta penuh pertimbangan. Pengambilan keputusan karir berkaitan dengan membuat pilihan terkait pendidikan, pelatihan dan pekerjaan (Patton \& McMahon, 2014).

Pengambilan keputusan karir bukanlah tugas yang mudah karena hal tersebut membutuhkan proses yang dinamis, seperti halnya menentukan pekerjaan yang sesuai dengan kemampuan diri. Memilih karir merupakan satu hal yang dialami setiap individu karena tidak ada seorangpun yang ingin menjadi pengangguran setelah menamatkan studinya (Supatmi, 2014). Oleh karena itu, pengambilan keputusan karir merupakan salah satu keputusan penting yang harus dilakukan oleh remaja (Hussain \& Rafique, 2013).

Pramudi (2015) juga melakukan studi wawancara terhadap beberapa siswa yang duduk di bangku kelas XI, diperoleh informasi bahwa terdapat beberapa siswa mengalami kesulitan dalam mengambil keputusan karir. Sebagian siswa merasa salah jurusan dan kesulitan menyesuaikan diri dengan jurusan pilihannya. Hal tersebut karena mereka belum matang dalam mengambil keputusannya. Siswa juga merasa bingung untuk melanjutkan ke perguruan tinggi dan belum siap ketika memasuki dunia kerja. 
Crites (1969) menemukan bahwa 30\% peserta didik merasa kebingungan semasa berada di sekolah sebagai akibat dari minimnya pengetahuan mereka tentang karir masa depan. Kurangnya informasi yang

\section{2}


akurat mengenai pemilihan karir menjadi salah satu penghambat remaja dalam mengambil keputusan karirnya secara tepat. Selain itu, peserta didik yang akan menamatkan studi tidak mempertimbangkan kesesuaian diri pribadi dengan karir yang hendak dituju. Hal ini menunjukkan peserta didik belum memiliki pengetahuan yang cukup untuk membuat pemilihan karir yang tepat. Pemilihan karir yang tepat tentunya harus disesuaikan dengan minat dan kemampuan remaja (Supatmi, 2014).

Sebuah penelitian dilakukan oleh Afzal, Atta dan Shujja (2013) untuk melihat pengaruh kecerdasan emosional terhadap pengambilan keputusan karir. Hasilnya adalah ada pengaruh yang signifikan kecerdasan emosional terhadap pengambilan keputusan karir. Dijelaskan juga pengaruh masing-masing dimensi kecerdasan emosional bahwa dimensi self emotions appraisal dan use of emotions memiliki pengaruh yang signifikan, sedangkan other"s emotions appraisal dan regulation of emotions tidak signifikan. Diasumsikan bahwa individu yang self emotions appraisal tinggi akan lebih menyadari minat, bakat dan kemampuan pada dirinya sehingga dapat mengambil keputusan karir dengan baik. Sedangkan, individu dengan use of emotions yang tinggi akan membuat individu lebih mampu memecahkan masalah terkait dengan pilihan karir (Mayer \& Salovey, 1997).

Selain kecerdasan emosional, variabel independen lainnya yang memiliki pengaruh terhadap pengambilan keputusan karir adalah gaya kelekatan. Ainsworth menjelaskan bahwa gaya kelekatan merupakan cara individu berinteraksi ataupun membuat hubungan dengan individu lain. Gaya kelekatan ini dibagi menjadi tiga, yaitu gaya kelekatan aman, cemas dan menghindar (dalam Akhtar, 2012). Penelitian yang dilakukan oleh Agheli, Abedi, Nilforooshan dan Baghban (2013) menunjukkan bahwa ada hubungan negatif antara gaya kelekatan menghindar dengan pengambilan keputusan karir rasional. Diasumsikan bahwa individu dengan gaya kelekatan menghindar, maka pengambilan keputusan rasionalnya rendah. Individu akan kekurangan informasi mengenai karir karena menghindari lingkungan sekitar dan tidak percaya dengan individu lainnya. Oleh karena itu, individu tidak mampu untuk membuat keputusan karir secara rasional.

Sedangkan, ada hubungan positif antara gaya kelekatan cemas dengan pengambilan keputusan karir intuitif. Individu 
dengan gaya kelekatan cemas memiliki kecenderungan untuk tidak melakukan hubungan dan menghindari individu lainnya. Oleh karena itu, individu tidak dapat membuat keputusan secara rasional sehingga lebih menggunakan intuisinya sebagai landasan berpikir. Ditemukan juga ada pengaruh signifikan antara 
gaya kelekatan cemas dengan pengambilan keputusan karir dependen. Berdasarkan latar belakang di atas, maka penulis mengidentifikasikan

masalah sebagai berikut:

1. Apakah ada pengaruh yang signifikan kecerdasan emosional dan gaya kelekatan terhadap pengambilan keputusan karir rasional pada siswa dan siswi SMA Negeri 36 Jakarta?

2. Apakah ada pengaruh yang signifikan kecerdasan emosional dan gaya kelekatan terhadap pengambilan keputusan karir intuitif pada siswa dan siswi SMA Negeri 36 Jakarta?

3. Apakah ada pengaruh yang signifikan kecerdasan emosional dan gaya kelekatan terhadap pengambilan keputusan karir dependen pada siswa dan siswi SMA Negeri 36 Jakarta?

4. Apakah ada pengaruh yang signifikan dimensi-dimensi kecerdasan emosional dan gaya kelekatan terhadap pengambilan keputusan karir rasional, intuitif dan dependen pada siswa dan siswi SMA Negeri 36 Jakarta?

\section{METODE}

Populasi dalam penelitian ini berjumlah 780, terdiri atas siswa dan siswi aktif tahun ajaran 2014/2015 kelas X, XI dan XII. Sampel berjumlah 237 orang. Kriteria yang menjadi sampel penelitian, yaitu merupakan siswa dan siswi aktif tahun ajaran 2014/2015 kelas X-XII dan terdiri dari laki-laki dan perempuan. Pada penelitian ini, peneliti menggunakan teknik nonprobability sampling yang berarti dalam suatu populasi, tidak semua elemen memiliki peluang untuk menjadi sampel penelitian ini. Peneliti melakukan pengambilan data dalam waktu satu minggu dengan melakukan penelurusan pada tiap jenjang kelas di sekolah yang menjadi populasi penelitian.

Instrumen penelitian yang digunakan dalam penelitian ini untuk pengambilan keputusan karir adalah skala yang dimodifikasi dari Assessment of Career Decision Making (ACDM) oleh Harren (1979). Skala kecerdasan emosional yaitu skala yang dimodifikasi dari skala kecerdasan emosional yang disusun oleh Wong dan Law (2004) dan skala gaya kelekatan oleh Ainsworth. (1987). Skala ini memiliki model skala Likert dengan empat pilihan jawaban. Uji validitas pada penelitian ini menggunakan Confirmatory Factor Analysis (CFA). Teknik analisis data yang digunakan adalah teknik regresi berganda. 
144 


\section{HASIL}

Berdasarkan hasil analisis data, diperoleh tiga hasil penelitian. Hasil penelitian pertama menunjukkan terdapat pengaruh yang signifikan antara kecerdasan emosional dan gaya kelekatan terhadap pengambilan keputusan karir rasional pada siswa dan siswi SMA Negeri 36 Jakarta. Nilai $R$-Square sebesar 0,184 yang menunjukkan bahwa secara keseluruhan variabel kecerdasan emosional dan gaya kelekatan memberikan sumbangan sebesar $18,4 \%$ terhadap bervariasinya pengambilan keputusan karir rasional pada siswa dan siswi SMA Negeri 36 Jakarta. Hasil penelitian kedua menunjukkan tidak ada pengaruh signifikan antara kecerdasan emosional dan gaya kelekatan terhadap pengambilan keputusan karir intuitif. Nilai R-Square sebesar 0,041 yang menunjukkan bahwa secara keseluruhan variabel kecerdasan emosional dan gaya kelekatan memberikan sumbangan sebesar $4,1 \%$ terhadap bervariasinya pengambilan keputusan karir intuitif pada siswa dan siswi SMA Negeri 36 Jakarta. Hasil penelitian ketiga menunjukkan terdapat pengaruh yang signifikan antara kecerdasan emosional dan gaya kelekatan terhadap pengambilan keputusan karir dependen pada siswa dan siswi SMA Negeri 36 Jakarta. Nilai $R$-Square sebesar 0,074 yang menunjukkan bahwa secara keseluruhan variabel kecerdasan emosional dan gaya kelekatan memberikan sumbangan sebesar 7,4\% terhadap bervariasinya pengambilan keputusan karir dependen pada siswa dan siswi SMA Negeri 36 Jakarta. Koefisien regresi masing-masing dimensi variabel independen terhadap variabel dependen dapat dilihat dalam tabel berikut.

\section{Tabel 1}

Koefisien Regresi Variabel Independen Terhadap Pengambilan Keputusan Karir

Rasional

Variabel

Koefisien Regresi

\section{Kecerdasan emosional}

1. Self emotions appraisal

2. Other"s emotions appraisal

3. Use of emotions

4. Regulation of emotions

.237 (no-sig)

.318 (no-sig)

.000 (sig)

.828 (no-sig) 
1. Gaya kelekatan aman

.091 (no-sig)

14

5 


\section{Variabel}

2. Gaya kelekatan cemas

3. Gaya kelekatan menghindar
Koefisien Regresi

.108 (no-sig)

.283 (no-sig)

Berdasarkan nilai koefisien regresi, use of emotions memiliki pengaruh yang positif dan signifikan terhadap pengambilan keputusan karir rasional pada siswa dan siswi SMA Negeri 36 Jakarta. Hal ini menunjukkan bahwa semakin tinggi use of emotions, maka semakin tinggi pula pengambilan keputusan karir rasional pada individu. Analisis lebih lanjut pada dimensi kecerdasan emosional menunjukkan hasil bahwa use of emotions memiliki peran utama dalam proses pengambilan keputusan karir dibandingkan dengan dimensi lain. Hasil penelitian ini dapat didukung secara logis bahwa penggunaan emosi tidak hanya membuat seseorang untuk memahami emosi, akan tetapi juga membuatnya mampu menggunakan emosinya dengan cara yang berguna. Oleh karena itu, diasumsikan bahwa kecerdasan emosional dan gaya kelekatan memiliki pengaruh yang signifikan terhadap pengambilan keputusan karir rasional.

Tabel 2

Koefisien Regresi Variabel Independen Terhadap Pengambilan Keputusan Karir

Intuitif

\begin{tabular}{cc}
\hline Variabel & Koefisien Regresi \\
\hline Kecerdasan emosional & \\
1. Self emotions appraisal & .062 (no-sig) \\
2. Other"s emotions & .313 (no-sig) \\
appraisal & .625 (no-sig) \\
3. Use of emotions & .920 (no-sig) \\
4. Regulation of emotions & \\
Gaya kelekatan & .896 (no-sig) \\
5. Gaya kelekatan aman & .874 (no-sig) \\
6. Gaya kelekatan cemas & .038 (sig) \\
7. Gaya kelekatan & \\
menghindar &
\end{tabular}

Ditemukan bahwa hanya satu dimensi yang signifikan, yaitu gaya kelekatan menghindar. Hal ini tidak sejalan dengan penelitian sebelumnya yang dilakukan oleh Agheli, Abedi, 
Nilforooshan dan Baghban (2013). Individu dengan gaya kelekatan menghindar memiliki kecerdasan

146 
emosional yang rendah, tidak mampu untuk melawan masalah, serta membuat keputusan yang tepat. Dalam beberapa situasi mereka tidak dapat membuat keputusan secara logis atau lebih secara intuitif. Individu juga cenderung merasa tidak aman dan cemas karena takut tidak mendapatkan dukungan dalam pengambilan keputusan karir masa depannya (Palos \& Drobot, 2010). Dalam penelitian ini ditemukan bahwa kecerdasan emosional dan gaya kelekatan tidak memiliki pengaruh yang signifikan terhadap pengambilan keputusan karir intuitif. Hal tersebut dikarenakan kontribusi variabel independen yang signifikan pengaruhnya terhadap variabel dependen tidak menghasilkan perubahan nilai yang besar sehingga menunjukkan tidak ada pengaruh.

\section{Tabel 3}

Koefisien Regresi Variabel Independen Terhadap Pengambilan Keputusan Karir

Dependen

\section{Variabel}

\section{Kecerdasan emosional}

1. Self emotions appraisal

2. Other"s emotions appraisal

3. Use of emotions

4. Regulation of emotions

\section{Gaya kelekatan}

5. Gaya kelekatan aman

6. Gaya kelekatan cemas

7. Gaya kelekatan menghindar
Koefisien Regresi
.037 (sig)

.442 (no-sig)

.199 (no-sig)

.004 (sig)

Dimensi yang memiliki pengaruh adalah self emotions appraisal secara positif dan regulation of emotions secara negatif. Peneliti berasumsi bahwa individu yang memahami dirinya dengan baik, maka mereka akan menyadari kelebihan dan kekurangan sehingga mengetahui batasan-batasan pada dirinya. Individu yang merasa kesulitan dalam mengambil keputusan karir akan membutuhkan pendapat dan dorongan orang lain. Regulation of emotions memiliki pengaruh yang signifikan secara negatif. Artinya semakin rendah kemampuan mengelola emosinya, individu akan kesulitan dalam mengambil keputusan karir sehingga seolah-olah menyerahkan keputusan karir tersebut kepada orang lain. Oleh karena itu, diasumsikan bahwa kecerdasan emosional 
dan gaya kelekatan memiliki pengaruh yang signifikan terhadap pengambilan keputusan karir

14

7 
dependen.

\section{DISKUSI}

Hasil penelitian dapat disimpulkan sebagai berikut:

1. Ada pengaruh yang signifikan antara kecerdasan emosional (self emotions appraisal, other"s emotions appraisal, use of emotions, regulation of emotions) dan gaya kelekatan (gaya kelekatan aman, gaya kelekatan cemas, gaya kelekatan menghindar) terhadap pengambilan keputusan karir rasional pada siswa dan siswi SMA Negeri 36 Jakarta.

2. Tidak ada pengaruh yang signifikan antara kecerdasan emosional (self emotions appraisal, other"s emotions appraisal, use of emotions, regulation of emotions) dan gaya kelekatan (gaya kelekatan aman, gaya kelekatan cemas, gaya kelekatan menghindar) terhadap pengambilan keputusan karir intuitif pada siswa dan siswi SMA Negeri 36 Jakarta.

3. Ada pengaruh yang signifikan antara kecerdasan emosional (self emotions appraisal, other"s emotions appraisal, use of emotions, regulation of emotions) dan gaya kelekatan (gaya kelekatan aman, gaya kelekatan cemas, gaya kelekatan menghindar) terhadap pengambilan keputusan karir dependen pada siswa dan siswi SMA Negeri 36 Jakarta.

\section{DAFTAR PUSTAKA}

Afzal, A., Atta, M., \& Shujja, S. (2013). Emotional intelligence as predictor of career decision making among university undergraduates. Journal of Behavioural Sciences, 23(1), 119-131

Agheli, M., Abedi, R.M., Nilforooshan, P., \& Baghban, I. (2013). Attachment styles and career decision making styles in Universities of Isfahan students. Interdisciplinary Journal of Contemporary Research in Business, 5(6), 404-413

Akhtar, Z. (2012). The effect of parenting style of parents on attachment

styles of undergraduate students

Crites, J.O. (1969). Vocational study of vocational psychology: The development. New York: McGraw Hill Hussain, S., \& Rafique, R. (2013). Parental expectation, 
salience and career decision making. Journal of Behavioural Sciences, 23(2), 62-76

Mayer, J. D., \& Salovey, P. (1997). What is emotional intelligence? In P. Salovey \& D. Sluyter (Eds), Emotional development and emotional intelligence: Implication for educators (pp. 3-34). New York: Basic 
Books

Munandir. (1996). Program bimbingan karier di sekolah. Jakarta: Jalan Pintu Satu

Palos, R., \& Drobot, L. (2010). The impact of family influence on the career choice of adolescents. Procedia Social and Behavioral Sciences, 2, 3407-3411

Patton, W., \& McMahon, M. (2014). Career development and systems theory: Connecting theory and

Rotterdam : Sense Publishers practice $\left(3^{\text {th }} \mathrm{Ed}\right)$.

Pramudi, H. (2015). Kemampuan pengambilan keputusan karir siswa

kelas XI di SMA Negeri 1 Kutasaro Purbalingga.

Skripsi. Universitas Negeri Yogyakarta

Sukardi, D.K. (1993). Psikologi Pemilihan Karier. Jakarta: Rineka Cipta Supatmi, T. (2014). Pengembangan bahan informasi bimbingan pemilihan

karir untuk meningkatkan kemampuan pengambilan keputusan karir siswa SMK Rumpun jurusan ekonomi. Jurnal. Universitas Sebelas Maret Surakarta 
14

9 
Pengaruh Kecerdasan Emosional dan Gaya Kelekatan terhadap Pengambilan Keputusan Karir 